症例

食道癌術後の化学療法による二次性骨䯣異形成症候群の 1 例

\begin{tabular}{|c|c|c|c|c|c|c|c|c|}
\hline & 熱函; & 15 & & & 大学 & 科* & & \\
\hline 原 & 正 & 田 & 仲 & & 曜* & 董 & 谷 & 武 \\
\hline 千 野 & 修* & 島 & 田 & 英 & 雄 ${ }^{*}$ & 幕 & 内 & 博 \\
\hline
\end{tabular}

症例は60歳, 男性. 平成12年 8 月初め頃より呼吸困難を自覚したため, 近医にて治療 を受けたが改善せず，9月 1 日当科に紹介となった．既往歴に44歳で喉頭癌に対し放射 線治療，56歳で食道癌に対し手術と直後に Cisplatin 100mg+5-Fluorouracil 5,000 $\mathrm{mg}+$ Leucovorin $150 \mathrm{mg}$ による術後化学療法を受けている. 血液検査ては白血球 $2,100 /$ $\mu 1$, 赤血球 165 万 $/ \mu 1$, ヘモグロビン $5.8 \mathrm{~g} / \mathrm{dl}$, 血小板 4.6 万 $/ \mu 1$ と㲸血球減少を呈していた. 当初は食道癌の再発とこれに伴う播種性血管内凝固症候群を疑い画像診断を中心に行っ たが，明らかな再発所見は認められなかった，しかし骨髄穿刺を行ったところ強い血球 形態異常と複雑な染色体異常が認められ，二次性骨髄異形成症候群と考えられた。この 疾患は化学療法や放射線療法の後 $6 \sim 8$ 年経過して認められることのある予後不良な二 次性腫瘍である.しかし, 今回再発との鑑別により良好な QOL を保つことが可能であっ たので報告する。

索引用語：二次性骨髄異形成症候群, 化学療法, 食道癌

\section{はじめに}

進行食道癌に対する治療は手術, 化学療法, 放射線 療法による集学的治療が行われている，化学療法の主 軸となるのは Cisplatin (以下 CDDP), 5-Fluorouracil (以下5-FU)である。一方で化学療法や放射線療法の 後,これらに誘発されたと考えられる二次性の血液疾 患としての骨髄異形成症候群 (以下 MDS) の発生をみ た症例の報告もある(12). 今回われわれは, 食道癌術後 の化学療法後 4 年で発症した二次性 MDS の 1 例を経 験したので報告する。

\section{症例}

症例：60藏, 男性.

主訴：呼吸困難.

既往歴：他院にて44藏で喉頭癌 (stage 不明)に対し 放射線治療を(詳細不明), 56嘁で食道癌 (adenosquamouscarcinoma, pT2, pN2, pStage III）に対し 右開胸開腹食道严全摘と直後に合計でCDDP 100 $\mathrm{mg}+5$-FU 5,000mg + Leucovorin 150mgによる術後

2002 年11月11日受付 2003 年 3 月 5 日採用

〈所属施設住所〉

于413-0005 熱海市春日町12-2
化学療法を受けている。なお平成 12 年 7 月に前医で施 行された血液検査ては白血球 $2,100 / \mu 1$ (band 15\%, seg $34 \%$, lympho $39 \%$, mono $10 \%$, eosino $2 \%$ ), へモ グロビン $9.5 \mathrm{~g} / \mathrm{dl}$, 血小板 11.1 万/ $\mu \mathrm{l}, \mathrm{CRP} 0.1 \mathrm{mg} / \mathrm{dl}$ て あった。

現病歴：平成 12 年 8 月初め頃より呼吸困難を自党し たため近医を受診。通院治療を受けたが改善ないため

\section{表 1 入院時検査所見}

\begin{tabular}{lrlr}
\hline RBC & $165 \times 10 \% / \mu \mathrm{l}$ & Glu & $145 \mathrm{mg} / \mathrm{dl}$ \\
$\mathrm{Hb}$ & $5.8 \mathrm{~g} / \mathrm{dl}$ & T.pro & $6.2 \mathrm{~g} / \mathrm{dl}$ \\
$\mathrm{Ht}$ & $16.1 \%$ & GOT & $16 \mathrm{IU} / 1$ \\
$\mathrm{Plt}$ & $4.6 \times 10 \% / \mu \mathrm{l}$ & $\mathrm{GPT}$ & $35 \mathrm{IU} / 1$ \\
WBC & $2.100 / \mu \mathrm{l}$ & $\mathrm{T} . \mathrm{bil}$ & $1.3 \mathrm{mg} / \mathrm{dl}$ \\
Baso & $0 \%$ & $\mathrm{LDH}$ & $561 \mathrm{IU} / \mathrm{dl}$ \\
Eosino & $0 \%$ & $\mathrm{BUN}$ & $16.0 \mathrm{mg} / \mathrm{dl}$ \\
Stab & $8 \%$ & $\mathrm{Cr}$ & $0.7 \mathrm{mg} / \mathrm{dl}$ \\
Seg & $60 \%$ & $\mathrm{Na}$ & $140 \mathrm{mEq} / 1$ \\
Lymph & $28 \%$ & $\mathrm{~K}$ & $4.5 \mathrm{mEq} / 1$ \\
Mono & $4 \%$ & $\mathrm{Cl}$ & $107 \mathrm{mEq} / 1$ \\
& & T.cho & $86 \mathrm{mg} / \mathrm{dl}$ \\
& & CRP & $0.2 \mathrm{mg} / \mathrm{dl}$ \\
& & SCC & $0.7 \mathrm{ng} / \mathrm{ml}$ \\
& & CEA & $1.9 \mathrm{ng} / \mathrm{ml}$ \\
\hline
\end{tabular}


表 2 骨髄像

\begin{tabular}{lcr}
\hline & 結果(\%) & \multicolumn{1}{c}{ 基準值 } \\
\hline 骨髄茅球 & 2.4 & $0.2 \sim 2.9$ \\
好中球 & & \\
前骨髄球 & 4.6 & $1.5 \sim 8.4$ \\
骨髄球 & 5.8 & $1.0 \sim 9.7$ \\
後骨髄球 & 13.8 & $3.6 \sim 14.6$ \\
桿状核球 & 12.6 & $10.6 \sim 24.6$ \\
分葉核球 & 2.0 & $8.5 \sim 33.2$ \\
リンパ球 & 8.2 & $5.0 \sim 32.6$ \\
単球 & 1.4 & $0.7 \sim 6.0$ \\
形質細胞 & 0.2 & $0.2 \sim 1.7$ \\
前赤芽球 & 2.0 & 0.14 \\
巨赤芽球様細胞 & 26.4 & - \\
多染性正赤芽球 & 3.4 & $4.1 \sim 29.1$ \\
正染性正赤芽球 & 17.2 & $0.1 \sim 5.7$ \\
\hline
\end{tabular}

9 月 1 日当科に紹介された.

入院時現症：身 長 $164 \mathrm{~cm}$, 体 重 $44 \mathrm{~kg}$, 血 圧 $112 / 60$ $\mathrm{mmHg}$, 脈拍 $112 / \mathrm{min}$, 体温 $37.4^{\circ} \mathrm{C}$, 眼瞼結膜は軽度筫 血様, 眼球結膜には黄疸なし。心音呼吸音清, 腹部平 坦軟, 表在リンパ節は触知せず。体幹四肢に出血斑や 浮腫は認めなかった。

入院時検查所見 (表 1 )：汎血球減少を認めた。血液 像では白血球分画は正常範囲内であったが赤血球の大 小不同を認めた。腫瘍マーカーは正常範囲内であった。

臨床経過：入院の後貧血と血小板数改善のため頻回 の濃厚赤血球・血小板輸血を要した。この結果, 分血 の改善に伴い呼吸困難も改善した。当初は食道癌の再 発を疑い，胸腹部 CT scan や上部消化管内視鏡などの 画像検査を行ったが再発の所見は認められなかった. 骨髄転移や血液疾患を検索するため骨髄穿刺を行い骨 髄像と染色体を調へたところ, 強い血球形態異常と極 めて複雑な染色体異常を細胞20個中 4 個に認めた（表 2, 図 1 ).以上の結果から二次性 MDS と診断した。 患者と家族に予後不良な疾患であること, 染色体異常 が強いためさらに予後不良が予測されること，治療と しては輸血などの対症療法の他化学療法・骨髄移植・ ホルモン療法などがあるがそれ程の効果は期待できな い旨を説明したところ, 本人は化学療法などの積極的 な治療は希望せず 9 月29日に退院された。以後外来に てほほ 3 日おきに濃厚赤血球や血小板を投与していた が，11月15日に発熱のため再入院した。この時，白血 球 $1,900 / \mu 1$, 赤血球 273 万 $/ \mu 1$, 血小板 0.1 万 $/ \mu 1$ であり, 血液像では異型リンパ球や骨髄球などが認められた。 以後敗血症となり抗生剤を投与したが反応せず，同月

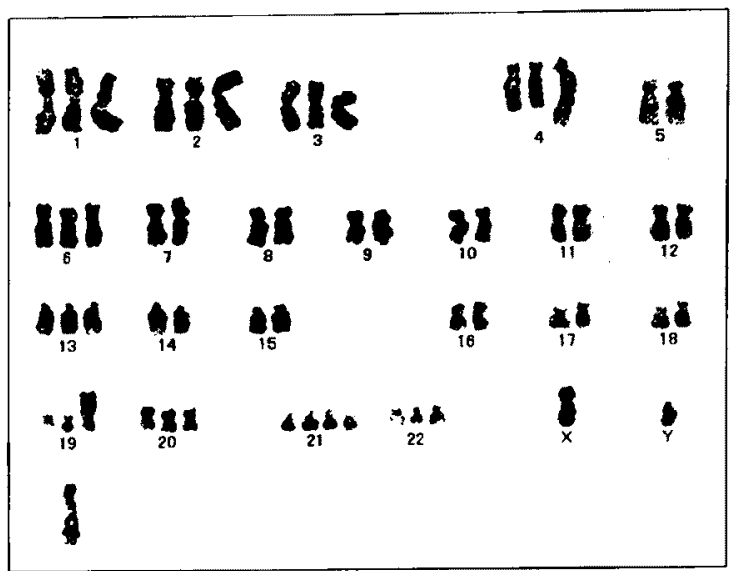

図1骨贱染色体分析：細胞20個中 4 個に染色体異常を 陻めた。 その中でも特に異常の著しいものを示す。く分 析 $>58,\langle 2 \mathrm{n}\rangle, \mathrm{XY},+1,+\operatorname{add}(2)(\mathrm{p} 23),+3,+$ der

(4) $\mathrm{t}(4 ; 11)(\mathrm{q} 35 ; \mathrm{q} 13),+6,+13,+$ add (19)

(p13), $+20,+21,+21,+22,+\operatorname{mar} 1$.

21日に永眠された.

考 察

骨髄異形成症候群 (myelodysplastic syndrome； MDS）には一次性と薬剈や放射線の影響により発症す る二次性 MDS がある゙．その病態は末梢血減少，正 ～過形成骨餚，血球形態異常を特徴とし，ともに白血 病に移行しやすいと考えられている231. 抗癌昘による 二次性 MDS は薬㶡によるDNA 損傷により造血前駆 細胞に遺伝子レベルでの異常が生じ，クローン化して いくと考えられている3．検査上の特徽的な所見とし て染色体異常があり，特に二次性 MDSでは高頻度に 認めることが報告されている4)5!。なかでも 5 番, 7 番 の染色体異常，また 3 種類以上の様々な染色体異常な どを認める場合には極めて予後不良と考えられてい $る^{10677}$. 上田 ${ }^{31}$ は二次性 MDS/白血病について平均発症 年齢は55.2歳, 予後の中央值は 8 力月と報告している. MDSの治療としては輸血の他, 骨䯣移植, シトシンア ラビノシドなどの化学療法, 副腎皮質ホルモンや蛋白 同化ホルモンによるステロイト゚ホルモン療法, G-CSF によるサイトカイン療法などがある2).

二次性 MDS は化学療法, 特にアルキル化剤を用い た場合や放射線療法を受けた後 $6 \sim 8$ 年, 報告によっ ては 4〜6年程経過して認められることもあると言わ れている(18) 10). 本症例は CDDP と代謝拮抗㓮である5 -FUによる化学療法を受けている. 投与された抗癌剈 は大量ではないが, 投与時期が発症の約 4 年前である 
表 3 消化器癌治療後に二次性 MDS/白血病をきたした本邦報告例

\begin{tabular}{|c|c|c|c|c|c|c|c|c|c|}
\hline & 年齢 & 性別 & 原疾患 & 手術 & 化学療法 & 放治 & 期間* & 治療 & 予後 \\
\hline 曹澤ら & 69 & $\mathrm{~F}$ & 結腸癌 & あり & $\begin{array}{l}\text { TGF, MMC } \\
5-F U\end{array}$ & なし & $3 \mathrm{Y} 4 \mathrm{M}$ & 化学療法 & 寛解 \\
\hline 中村ら ${ }^{19)}$ & 70 & M & $\begin{array}{l}\text { 直腸癌 } \\
\text { 胃癌 }\end{array}$ & あり & UFT & なし & $1 Y 1 M$ & 化学療法 & 宽解 \\
\hline 棟方ら ${ }^{20)}$ & 63 & M & 周㴦 & あり & TGF & なし & 不明 & 化学療法 & $6 \mathrm{M}$ \\
\hline 松崎ら 211 & 63 & M & 食道癌 & あり & CDDP & あり & $4 Y 1 M$ & 化学療法 & $1 \mathrm{M}$ \\
\hline 松崎 5211 & 63 & M & 食道癌 & あり & $\begin{array}{l}\text { CDDP, ADM } \\
\text { MMC, } 5-F U \\
\text { PEP }\end{array}$ & あり & $1 \mathrm{Y} 10 \mathrm{M}$ & 化学療法 & $4 \mathrm{M}$ \\
\hline 自験例 & 60 & $\mathbf{M}$ & 食道瘦 & あり & CDDP, 5-FU & あり** & $4 Y 3 M$ & 対症療法 & $3 \mathrm{M}$ \\
\hline
\end{tabular}

こと, 強い血球形態異常と極めて複雑な染色体異常を 認めたことから二次性 MDS と診断した。また本症例 は前述の理由から極めて予後が不良と考元られ，患者 や家族との相談のうえ輸血による対症療法のみを行 い, 診断から約 2 力月で永眠された。しかし早期に診 断をつけることができたため，入院期間を短縮でき外 来で輸血を行いながら通院で経過をみることが可能で あった。もしこのまま経過していれば白血病化の可能 性も考えられた。

過去に報告された二次性 MDS/白血病には発症前 に治療された原疾患として, 非腫瘍性疾患では肺結核 に対するリファンピシンが原因と考えられる症例の報 告がある゙1。腫瘍性疾患としては皮膚腫瘍5), 精巣腫

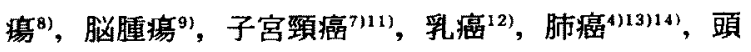
頸部腫瘍 ${ }^{15) 16)}$, 造血器腫瘍(17)などの報告が散見され る.今回のように食道癌術後の化学療法が原因と考え られた症例は検索しえた限りでは自験例を含め 3 例で あった，消化器癌に限ってみると6 例の報告があり， いずれも消化管の癌であった(表 3$)^{(8) ~ 21) . ~ し か し こ れ ~}$ らの報告例にはアルキル化剤を投与された症例はな い. 消化器癌の化学療法で CDDP などの白金製郕や5FU 等の代謝拮抗剤と比較し,アルキル化剂を使用す る頻度がかなり低いためと思われる。また食道癌自体 は消化器癌の中で頻度が低いものの, 今回の検索では 自験例を含め 6 例中 3 例が食道癌であった。これは進 行癌の経過中に著明な血小板減少を伴う汎血球減少を 呈した場合, 癌の進行に伴うDICゃ骨髄転移などと診 断され二次性 MDS との診断に至らなかった症例が存 在しているためと推祭される.

消化器の進行・再発癌は化学療法を必要とする頻度
が高い。その中で二次性 MDS を発症する症例は極め て稀であると思われるが，化学療法後に汎血球減少を 呈した場合には再発の他, 二次性 MDS も念頭に誩断 をすすめることが必要と考えられた。

結語

1. 食道癌術後の化学療法が原因と考えられた二次 性 MDSの1例を経験した。

2. 化学療法後数年して汎血球滅少を呈した場合に は再発だけでなく，二次性 MDS も念頭に置くことは 重要と思われた.

本稿を終えるにあたり御指導を賜りました森田クリニッ クの増本 暁先生に深謝致します。

\section{文献}

1) 高橋 敦, 名越温古, 山川珠美他：薬剤性骨髄異 形成症候群が考えられた 2 例. 臨血 $37: 53-59$, 1996

2）柴田 昭, 池田康夫, 堀田知光他：エッセンシャ ル血液病学. 第 5 版, 医荘荣出版, 東京, 1999, p129-133

3）上田恭典：2 次性 MDS. 臨科学 $31: 176-184$, 1995

4）福西恵一, 黒川晃夫, 竹下 篤他：放射線,化学 療法後に急性骨髄性白血病, 形質細胞腫を発症し た肺小細胞癌の長期生存例. 日呼吸会誌 $37: 415$ $-419,1999$

5）垂水千早，延藤俊子，幸田 衒他：慗性黑色堙の 治療中に発生した二次性骨葡異形成症候群. 臨皮 $51: 761-763,1997$

6) 北林 淳, 大鳴厚志, 朝倉健一他: 染色体異常 20 $q$-を伴う二次性 MDS を発症した多発性骨随腫の 
1例. 血腫㾌 $28: 296-300,1994$

7) 花村明利, 市川 篤：MDS (RAEB in T) と当 初診断された $\mathrm{t}(8 ； 21)$ を伴う治療関連性白血 病. 臨血 36:755-761, 1995

8）山田裕二, 武中 篤, 島谷 昇他：精巣腫瘍治療 後二次性骨稙異形成症候群を発症した 1 例，泌外 $7: 971-973,1994$

9）小林聖子，沢田圭司，榊原吉峰他：䀎薄芽腫に対す る MOPP 療法後に発症した骨䯣異形成症候群. 小児臨 $50: 239-243,1997$

10）梅田Uろ子，木下律子，川崎幸子他：二次性 AML/MDS の 5 例. 新潟臨衛検技師会誌 36 ： $207-212,1996$

11）長谷川正規，中瀬一則，鈴木宣則他：5q-を伴う 二次性骨髄異形成症候群の 1 例. 山田赤十字病誌 $13: 115-119,1995$

12）演野一將, 山野 繁, 川野貴弘他: 乳癌の化学療 法後に骨鹃有異形成症候群を発症した高龄者末期腎 不全の1例. 奈良医誌 $50: 333-337,1999$

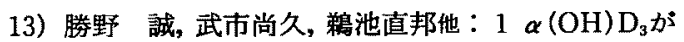
奏効した二次性骨貹道異形成症候群の 1 例. 臨と研 $68: 775-778,1991$

14）上村 学, 笠松美宏, 沢田 学他: 肺癌化学療法
中に骨髄異形成症候群 (MDS) を発症した 1 例.

日胸疾患会誌 $30: 1825-1829,1992$

15）井口芳明, 小川克二, 山本一博他：頭䅡部悪性腫 瘍の治療後に発症した骨髄異形成症候群の 1 例.

耳蕆・頭頸外科 $72: 264-267,2000$

16）秋定 健, 折田洋造, 吉弘剛他: 喉頭淿治療中 に発症した骨髄異形成症候群。耳鼻臨床 90 ： $1393-1397,1997$

17）稲田浩子, 江口春彦, 栗谷典量他: 二次性骨髄異 形成症候群の 4 例. 日小児臨楽理会誌 9:81一 83,1996

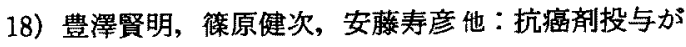
原因と思われる二次性白血病の 2 例. 癌の蹦 $42: 319-324,1996$

19) 中村隆光, 橋本起一郎, 千川就可他: 抗癌龵に上 り発症したと思われる二次性 MDS の 2 例. 臨血 $36: 1121,1995$

20）棟方正樹, 秋山昌希, 対馬健一他：二次性白血病 4 例の臨床的検討. 血腫瘰 $29: 224-230,1994$

21）松崎郁夫, 阿保七三郎, 北村道彦他：食道潞衍後 補助療法後に発症した二次性白血病の 2 例. 癌の 臨 $43: 45-49,1997$

\title{
A CASE OF SECONDARY MYELODYSPLASTIC SYNDROME DUE TO CHEMOTHERAPY AFTER SURGERY FOR ESOPHAGEAL CANCER
}

\author{
Tadashi HARA, Hikaru TANAKA*, Takehiko KAMEYA*, Osamu CHINO*, \\ Hideo SHIMADA* and Hiroyasu MAKUUCHI* \\ Department of Surgery, Nekkan Hospital \\ -Department of Surgery, Tokai University School of Medicine
}

\begin{abstract}
A 60-year-old man referred on September 1, 2002, for a 1-month history of nonresponsive dyspnea had undergone radiotherapy for laryngeal cancer at age 44 and surgery for esophageal cancer followed by chemotherapy with cisplatin $100 \mathrm{mg}+5$-fluorouracil $5000 \mathrm{mg}+$ leucovarin $150 \mathrm{mg}$ at age 56 . Blood examination showed a white blood cell count of $2100 / \mu 1$, red blood cell count of $1650,000 / \mu 1$, hemoglobin of $5.8 \mathrm{~g} / \mathrm{dl}$, and platelet count of $46,000 / \mu 1$, indicating pancytopenia. Recurrence of esophageal cancer with disseminated intravascular coagulation syndrome was initially suspected and imaging conducted, but no findings of recurrence were found. Bone marrow puncture showed significant morphological abnormality of blood cells and complicated chromosomal aberration. Secondary myelodysplastic syndrome was considered. We diagnosed a secondary tumor with poor prognosis appearing $6-8$ years after chemotherapy and radiotherapy. Successfully differentiating this case from recurrent esophageal cancer, however, led to good quality of life for the patient.
\end{abstract}

